\title{
Chapter 5 \\ The Changing Waves of Migration from the Balkans to Turkey: A Historical Account
}

\author{
Ahmet İçduygu and Deniz Sert
}

This chapter elaborates on the migration flows from the Balkans into Turkey, taking a historical approach. In doing so, it focuses particularly on migration from that part of the Balkans consisting of Albania, Bulgaria, Greece, Romania, and former Yugoslavia ${ }^{1}$ within four historical periods. The first period looks at emigration from these countries into Turkey during the late Ottoman period, beginning with the decline of the Empire. The second period describes the waves of Balkan migration into the newborn republic of Turkey until the end of World War II. Over this period there were two concerns of the founding fathers of the Turkish Republic: (i) the matter of the declining population of the country from 16 million in 1914 to around 13 million in the 1920s (Courbage and Fargues 1998, p. 128); and (ii) the issue of creating a homogenous sense of national identity in an otherwise ethnically and culturally diverse country. This latter concern was very much driven by a deep-seated belief that the Ottoman Empire had collapsed because of its multiethnic and multicultural nature (Ahmad 1993). Thus, the immigration policy pursued during this period was to encourage and accept immigrants who could speak the Turkish language and had an affiliation with Turkishness. In practice, however, those who belonged to a Sunni-Hanafi religious background were given preferential entry (Kirişci 1996, 2000). ${ }^{2}$ Accordingly, the groups that were supposedly easier to melt into a Turkish identity were mostly Muslim Albanians, Bosnians, Circassians, Pomaks, and Tatars.

\footnotetext{
${ }^{1}$ Owing to the fact that Yugoslavia did not exist as a country before 1929, it is taken here as a region at least until this date.

${ }^{2}$ The selection criteria for the period were not clear while conceptions of Turkishness were very vague.
}

\author{
A. İçduygu ( $\square)$ \\ MiReKoç, Koç University, Istanbul, Turkey \\ e-mail: aicduygu@ku.edu.tr \\ D. Sert \\ Department of International Relations, Özyeğin University, Istanbul, Turkey \\ e-mail: deniz.sert@ozyegin.edu.tr
}

(C) The Author(s) 2015. This book is published with open access at SpringerLink.com

H. Vermeulen et al. (eds.), Migration in the Southern Balkans, IMISCOE Research Series,

DOI 10.1007/978-3-319-13719-3_5 
The third period - between the end of World War II and the end of the Cold War-witnesses a transformation of Turkey's above-mentioned immigration policy into one that discouraged immigration on the grounds that Turkey's population had grown sufficiently and that land to distribute to immigrants had become scarce. Nevertheless, immigration during this period did continue with the migration of ethnic Turks and Muslims, in particular, with flows from Greece and Bulgaria; the latest large wave occurred in 1989 when more than 300,000 Turks and Pomaks were expelled from Bulgaria.

The fourth period - since the end of the Cold War - expands on both change and continuity in the nature of migration to Turkey from the Balkan countries under consideration. For example, while migration from Yugoslavia into Turkey during the break-up of the country did resemble the migration wave from Bulgaria in 1989, the return migration from Turkey to Bulgaria (caused by regime change in the latter in 1990 as the Cold War came to an end) was a rather new phenomenon. This trend of return was recently reinforced by Bulgaria's accession to the EU, when more and more of these migrants - that is, Turkish- and Bulgarian-speaking Muslims - reclaimed Bulgarian citizenship ${ }^{3}$ in order to obtain the right to travel to Bulgaria and other EU countries without a visa. At the same time, the nature of immigration from the Balkans into Turkey is changing from permanent to temporary with increasing two-way transit irregular migration. To illustrate, Parla (this volume) wonderfully describes how Turkish-speaking migrants from Bulgaria have transformed from a group of migrants who were historically the most privileged among migrant groups in Turkey to a group whose legal status has so shifted over the last two decades to become one of systematic irregularity.

Since the establishment of the Turkish Republic in 1923, more than 1.6 million immigrants from the Balkans have come and settled in Turkey; we argue that over time there have been changing patterns in these migration flows and in the migrants' characteristics. These changes reflect the dramatic transformations in the region throughout the twentieth century-initially through nation- and state-building, and more recently via globalization processes that have altered social, economic, and political structures in the Balkans.

There is a methodological concern that should be noted here. This study largely benefits from the analysis of secondary data and literature, which should not be seen as a deficiency for several reasons: (i) no single comprehensive study has been conducted on the migration flows from the Balkans to Turkey; (ii) existing studies are sketchy and limited; and (iii) a study that is broad enough to cover the issue thematically and historically is lacking. Thus, this study tries to go beyond what has been said before, as it presents a cross-temporal and cross-country analysis.

\footnotetext{
${ }^{3}$ Such people retain their Turkish citizenship as both countries allow dual nationality.
} 


\title{
5.1 The Late Ottoman Period
}

\author{
Crying, while crying \\ With the ballad of coy Bodin from Tuna \\ With the anthem of Algeria from Africa \\ With the elegy of 'O veterans!' from the seas of Arabia \\ We migrated to the land of Anatolia... ${ }^{4}$
}

The Ottomans' reign in the Balkans lasted almost 400 years until the late nineteenth century when there was an emerging Russian influence in the region. Although the signs of decline had become evident much earlier with the Serbian (1804-1835) and Greek (1814-1827) revolutions, it was really with the loss of the 1877-1878 Russian-Ottoman War that the Ottoman Empire began to lose its importance in the region. Stola (1992, p. 328) states:

The Ottoman Empire was the first of the multinational empires in Central Europe to decline and retreat. Turkish reprisals for rebellions and mutual hostility between Muslims and Christians generated thousands of refugees, who moved between Turkey and its former provinces, especially after the territorial changes caused by the Russian-Turkish war of $1877 \ldots$ Up to $1912 \ldots$ the inflow of Muslim refugees apparently doubled the population of Constantinople.

As Albania, Bulgaria, Greece, Montenegro, Romania, and Serbia established their nation states and embarked on their policies of creating homogeneous ethnic societies, Turks and non-Turkish Muslims (e.g., Cretan Muslims, Pomaks, Roma, Torbesh, and Vallahades) of the region began to search for new homes in the Anatolian peninsula (Duman 2008, p. 23; İpek 1999, pp. 14-21; Todorova 1997, pp. 348 349). This was a rather new migration flow: instead of the historical East to West migrations of the Turks to the newly conquered Ottoman territories, this migration was from the West to the East - this time from the lost lands to the safe haven of Anatolia. It was in this context that the Greek revolt was accompanied by the slaughter of many Muslims and the flight of many others (McCarthy 1995). Most of these refugees went just northwards to a part of the Balkans still under Ottoman control rather than to what is now Turkey. Many of them, however, undoubtedly migrated to Turkey at a later stage.

It is important to underline that in this late Ottoman period, religion rather than language was the defining characteristic of these flows. Even in the succeeding early Republican period, immigration was defined more in religious than in linguistic terms - that is, it was enough to be a Muslim to settle in the country. Eventually, the Treaty of Lausanne of 1923 was also drawn up with this rationale, where religious rather than ethnic minorities were the main concern. Thus, it is rather hard to distinguish between these categories for those periods where the words 'Turk' and 'Muslim' were used interchangeably. As explained by İçduygu et al. (2007, p. 359):

\footnotetext{
${ }^{4}$ Translated by the authors from the Turkish original: '...Biz, Tuna'dan 'Nazlı Bodin' türküsüyle, Afrika'dan 'Cezayir Marşı 'ile, Arabistan denizlerinden 'Ey Gaziler' mersiyesi ile ağlaya ağlaya, Anadolu toprağına göçettik...' (Atay 1970, p. 86).
} 
Despite the use of the category of 'Turk' as a building block of the nation-state, what this word referred to was initially ambiguous and this ambiguity was to persist, with the definition and content of 'Turk' undergoing changes in different eras, subject to the influence of events and developments (Kadığlu 1998). 'Turk' was used to refer sometimes to an ethnic group originating in Central Asia, sometimes to a legal status of citizenship on the basis of identity cards and passports and sometimes to individuals sharing a common culture, i.e. Turkish culture (Deringil 2000). As to the religion of the 'Turk', Islam was frequently used to define Turks, the Turkish nation and Turkish culture. In other words, Islam provided a reference point in the definition of the ordinary Turk (Kirişci 2000; Meeker 2002; Özbudun 1998; Özdoğan 1996). As a result, the inclusion of non-Muslims has been problematic in the normative definition of 'Turk'. (Keyman and İçduygu 1998)

There were two substantial migration waves from the Balkans during the late Ottoman period predating the founding of the Turkish nation state. The first consisted of migrations that occurred during the Russian-Ottoman War of 1877-1878, which marked the beginning of the dissolution of the Empire and caused more than a million Muslims to be uprooted (Kocacık and Yalçın 2008; McCarthy 1995); the second wave was during the Balkan Wars of 1912-1913, during which approximately 200,000 Turks died and another 440,000 migrated from Thrace and Macedonia in the aftermath of the wars until the Republic was founded (Eren 1993, pp. 292-293). Hence, both events caused Muslims' retreat from the lost territories of the Ottoman Empire.

Especially following the latter, the admittance and settlement of the population dislocated from the lost territories became one of the major issues that the ruling Unity and Progress Party (Ittihak ve Terakki hereafter) of the Young Turks had to tackle (Dündar 2001, p. 121). The most important tool that Ittihak ve Terakki used to deal with the issue was the signing of population exchange agreements. With the changes in the borders and the emergence of new nation states in the aftermath of the Balkan Wars, the newborn states began to pursue ways to create a homogeneous population within their new borders. Thus, the population exchange agreements were regarded as the most legitimate way of achieving this goal. Within this framework, the first voluntary population exchange agreement was part of the Treaty of Constantinople (also known as the Treaty of Istanbul), which was a treaty between the Ottoman Empire and the Kingdom of Bulgaria signed on 29 September 1913 in the Ottoman capital Istanbul after the Second Balkan War (Babuş 2006; Dündar 2001, p. 60). The main terms of the treaty were: (i) Bulgaria acknowledged Ottoman gains of Edirne, Kirklareli, and Demotika (Didimoteicho) and the surrounding territory; (ii) the Ottoman Empire ceded the port of Dedeagach (now Alexandroupoli) to Bulgaria; (iii) the exchange of lands was to be completed within 10 days; (iv) the armies on the border would be demobilized within 3 weeks; (v) prisoners of war from both sides would be released; (vi) both political and economic ties between the two countries would be re-established; and (vii) the voluntary exchange of population would be organized within the next 4 years (see Anderson and Hershey 1918). It was at this point that 47,000 Bulgarians in Ottoman Thrace left their homes in return for 49,000 Turks being accepted into Turkey from Bulgaria (Psomiades 1968, p. 60).

In fact, most of the population was already subject to forced displacement during the wars, and the agreements were only relevant for smaller populations (Tekeli 1990, p. 60). Beyond population exchange, the agreements also stipulated exchange 
of properties, protection of property rights, and guarantee of the rights of minority populations left behind. However, a year after the Balkan Wars-with the advent of World War I-many such agreements were nullified and the population exchange process was halted.

A second tool that Ittihak ve Terakki utilized to manage the problem of displaced populations was the combination of conscription and resettlement strategies, which first targeted the resettlement of migrants from the Balkans to nearby border regions in Thrace, where the cities and towns were mostly inhabited by non-Muslim populations (Ağanoğlu 2001, p. 110). Those newly arrived Muslim migrants were not only settled in these regions, but male immigrants were also conscripted in the same regions. Consequently, this strategy served both external and internal security purposes. Looking at the records of the Ministry of Interior of the time, Dündar (2001, pp. 71-72) argues that the combination of resettlement and conscription was an essential mode of 'Turkification' of those areas with insufficient Turk and Muslim populations within the Empire (see also Ulukan 2008).

The censuses were the third policy that Ittihak ve Terakki employed as a means of controlling population movements. Realizing that it was important to know the number of outgoing non-Muslim populations in order to be able to settle the incoming Muslim populations in an efficient manner - that is, making the population within the borders as Turkish and Muslim as possible - unofficial censuses were conducted and Anatolia's ethnic and religious distribution was figured out. Population movements were closely scrutinized and ethnographic maps of the Ottoman state were drawn (Dündar 2001, pp. 71-72; Ulukan 2008).

All in all, the policies pursued by Ittihak ve Terakki, motivated by Turkish nationalism, designated the ethnic and religious distribution of the contemporary Anatolian peninsula. Migration and settlement policies largely focused on creating a homogeneous Turkish and Muslim community - rather than economic interests, human conditions, and/or utilization of unused land for production.

Within this context, Albanians are an illustrative case. Until the independence of Albania was proclaimed in 1912, voluntary migration and the devşirme $e^{5}$ practice had caused an emergence of Albanian presence in the Ottoman army and administration in Istanbul (De Rapper 2000). Migration of Albanians to Istanbul continued even during the early years of the Albanian state, as the government could exercise its authority in only a small part of the territory - the rest being occupied by the Greeks in the south, and by the Serbs and Montenegrins in the north. Violence and insecurity caused many Albanians to flee. Istanbul was a major destination for two reasons. First, many Albanians already had relatives or friends in the Ottoman capital and could count on the support of established networks. Second, rural Albanian populations were mostly Muslim. They did not have a developed Albanian national consciousness and were accustomed to being referred to as 'Turks' (a religious category rather than a national or ethnic community); thus, the Ottoman Empire and

\footnotetext{
${ }^{5}$ It is translated as 'collection of children', 'child-gathering', or 'blood tax' in different Balkan languages. This was the practice by which the Ottoman Empire recruited boys, forcibly, from Christian families, who were selected by skilled scouts to be trained and enrolled in one of the four imperial institutions - the Palace, the Scribes, the Religious, and the Military.
} 
Turkey seemed a natural destination (De Rapper 2000). In this case, the definition of the category 'Albanian' had different meanings: on one hand, albeit to a lesser extent, it referred to those groups of people with Albanian nationality (ibid.). On the other hand, it referred to those ex-Yugoslavs in Albania and Greece who were recognized as of Albanian origin based on personal experience or verified familial ties (ibid.). Thus, a subjective definition of Albanian is being utilized that reposes on the identification of the people to the 'Albanian' category, and that does not take into consideration objective criteria like nationality (citizenship), language, or birthplace. As seen in the next section, especially for Albanian Muslims from western Greek Macedonia, such a subjective categorization proves to be problematic; however, there is no better classification owing to a lack of accurate data on the characteristics of the people in the region (i.e., their origins).

\subsection{The Early Years of the Republic}

We want a numerous population, a satiated population, a happy and affluent population. Against the history that left Anatolia empty, poor, old and ruined, we have a grudge that is growing every day. The energy of creating a numerous, happy and affluent Anatolia is coming from the force of this growing grudge. Today's Anatolia that we took over from the past government is in its most desolate and neglected position in its history. If we do not at least double the number of this population of fourteen million, whose entire civil capabilities have been unnoticed, whose needs are diminished, and who is almost ignored of civilization, in a rather short period of time, we would jeopardize our survival against the populous and technologically developed nations of the future. Under its perished nature that seems to be desolate, Anatolia is an untouched country that hides all the conditions of a life in heaven. This country is waiting for the Turkish nation to get crowded and numerous. Our target is a technologically developed, satiated, happy and numerous Turkish nation (Aydemir 1932, p. 35).

The founding fathers of the Turkish Republic were troubled by the recently reduced population of the country. The decrease was not only the result of the wars, but also of the towering death rates owing to general lack of health care, and to illnesses such as malaria, syphilis, trachoma, typhoid, and dysentery (Duman 2008, p. 24). Within this context, the founding fathers sought the means of generating a homogeneous sense of national identity in a fragile country that was otherwise ethnically and culturally diverse (İçduygu and Kirişci 2009). Thus, people who were either Muslim Turkish speakers or could easily melt into a Turkish identity (such as Bosnians, Circassians, Pomaks, and Tatars from the Balkans) were given exclusive priority and accepted as immigrants into the country (Kirişci 1996, 2000). ${ }^{6}$ From

\footnotetext{
${ }^{6}$ The immigration of Turks from Western Thrace was an exception. According to Article 2 of the Exchange Agreement between Greece and Turkey, which comprised 19 articles and which was appended to the Lausanne Treaty, the Greeks in Istanbul and the Turks in Western Thrace were to be excluded from exchange. For strategic reasons, Turkish governments did not view immigration from Western Thrace positively. For a detailed elaboration, see Öksüz (2004).
} 
the foundation of the Republic in 1923 until 1997, more than 1.6 million people migrated to Turkey, settled in the country, and were successfully assimilated.

The demographic conditions that the Republic of Turkey inherited from the Ottoman Empire are known to be the result of the Russian-Ottoman War of 1877-1878 and the subsequent wars, which caused the uprooting of many Muslim migrants from various ethnic backgrounds (Ulukan 2008, p. 47). During the years of the dissolution of the Ottoman Empire, many immigration flows took place - mainly from the Balkans, the Aegean Islands, Cyprus, Hatay, ${ }^{7}$ the Middle East, and the Soviet Union (Çağaptay 2002; Ulukan 2008). The immigration of the Muslims caused drastic demographic changes in the proportion of non-Muslims within the population: before World War I, while one in every five persons was a non-Muslim within the geography consisting of the territories of the Republic, after the war this ratio had decreased to one in every 40 persons (Keyder 1989, p. 67; Table 5.1).

With such changing demographic conditions, the issues of settling the newcomers as well as homogenizing the new population became important items on the agenda of the founding fathers. Accordingly, the 1926 Law of Settlement - the first significant official text governing voluntary immigration - charged the Ministry of Internal Affairs with the tasks of admitting the immigrants and refugees to the country, and of determining their regions of settlement as well as stating who could not be admitted as an immigrant or refugee (Ulker 2007). Thus, based on Article 2 of the law:

People who do not belong to Turkish culture, who are infected with syphilis, who are subject to leprosy and their families, who are imprisoned because of committing murder except political and military reasons, anarchists, spies, gypsies, or who are exiled outside of the country cannot be admitted.

Table 5.1 The Muslim and non-Muslim population in Turkey, 1914-2005 (in thousands). (Source: İçduygu and Kirişci 2009, p. 2)

\begin{tabular}{l|r|r|r|r|r|r}
\hline Year & \multicolumn{1}{|c|}{1914} & \multicolumn{1}{|c|}{1927} & \multicolumn{1}{c|}{1945} & \multicolumn{1}{c}{1965} & \multicolumn{1}{c}{1990} & \multicolumn{1}{c}{2005} \\
\hline Muslims & 12,941 & 1329 & 18,511 & 31,139 & 5686 & 71,997 \\
\hline Greeks & 1549 & 110 & 104 & 76 & 8 & 3 \\
\hline Armenians & 1204 & 77 & 60 & 64 & 67 & 50 \\
\hline Jews & 128 & 82 & 77 & 38 & 29 & 27 \\
\hline Others & 176 & 71 & 38 & 74 & 50 & 45 \\
\hline TOTAL & 15,997 & 13,630 & 18,790 & 31,391 & 57,005 & 72,122 \\
\hline Percentage of non-Muslims & 19.1 & 2.5 & 1.5 & 0.8 & 0.3 & 0.2 \\
\hline
\end{tabular}

\footnotetext{
${ }^{7}$ Hatay was part of Aleppo in Ottoman Syria. Following World War I, Hatay (then known as Alexandretta) was under the French Mandate of Syria. Unlike other regions historically belonging to Syrian provinces, Alexandretta was considered as Syrian territory in the Treaty of Lausanne, but it was granted a special autonomous status because it contained a large Turkish minority. Concomitant to a series of border disputes with France-mandated Syria, in 1937 an agreement was signed with France recognizing Alexandretta as an independent state, and in 1939 following a referendum this state, called the Republic of Hatay, was annexed to Turkey as the 63rd Turkish province.
} 
Thus, this law linked the admission of immigrants and refugees to the condition of belonging to Turkish culture. However, who was to be considered within this category was not specified in the law. Indeed, beside the Muslim-Turk population living outside the borders of the Republic, this category also referred to the non-Turk, but Muslim, ethnic and linguistic groups, especially from the Balkans. Here culture very much refers to being Muslim, which was a deviation from Ziya Gökalp's idea of Turkish culture being based on religion, language, a common history and values. Thus, with this law, while the conditions of resettlement of Ottoman Muslims were alleviated, non-Muslim Ottoman subjects' resettlement to the country was outlawed (Çağaptay 2002, p. 225; Ulukan 2008, p. 50). This importance given to religion was in contradiction to the secular foundations of the Republic, a major paradox of the initial years:

While seeming to reject their Ottoman and Islamic heritage, the new regime (Republic) still continued to respect the common historical heritage with those non-Turkish groups [of Bosnians, Albanians, and Macedonians]. Those groups were placed within the Muslim millet $^{8}$ in the Ottoman Empire, and, it might be argued, there is a reflection of that millet system in the Turkish Republic in its recognition of the groups that previously were parts of the Muslim millet as Turks (İçduygu et al. 1999, pp. 195-196)

As time passed, the 1926 Law of Settlement on population problems proved to be inefficient, and it was decided that a more general settlement law was needed. Thus, the 1934 Law of Settlement came to be the most comprehensive law of its time - not merely regulating only migration or settlement, but really a tool for creating a homogeneous national identity of the 'new Turk' (Kirişci 2000, p. 4). The law aimed at increasing the population and production capacity, attaching the refugees and immigrants to the national culture, settling nomadic populations and providing them with land, teaching everybody the Turkish language and their citizenship rights, and thus, creating a nation to protect the unity and security of the state (Babuş 2006, p. 298; Ulukan 2008, p. 51).

According to the 1934 Law of Settlement, only those of Turkish descent and culture would be accepted as immigrants in Turkey. In practice, this excluded nonMuslim Turks (like the Gagauz Turks), but included non-Turkish Muslims (like Pomaks, Tatars, and Bosnians). However, the law did not define who was of Turkish descent and culture, but left the matter to be determined by the Council of Ministers. Looking at Table 5.2, it can easily be observed that the people from the Balkansthat is, from Bulgaria, Greece, Romania, and Yugoslavia - were the largest group who migrated to Turkey.

Thus, immigration from the Balkans comprised an important part of the immigration history of the Republic. Some of these movements were a result of population exchange agreements signed after the War of Independence. For example, the agreement on the 1923 Turkish-Greek population exchange, which was signed in Lausanne, was an important historical document. Nearly 900,000 out of

\footnotetext{
${ }^{8}$ Millet is a term for the confessional communities in the Ottoman Empire, referring to the separate legal courts pertaining to 'personal law' under which communities (Muslim Sharia, Christian Canon law, and Jewish Halakha law abiding) were allowed to rule themselves under their own system.
} 
Table 5.2 Migrations to Turkey by region of origin and time period (1923-1997). (Source: İçduygu and Kirişci 2009, p. 10)

\begin{tabular}{l|l|l|c|c}
\hline Region of origin & $1923-1939$ & $1940-1945$ & $1946-1997$ & TOTAL \\
\hline Bulgaria & 198,688 & 15,744 & 603,726 & 818,158 \\
\hline Greece & 384,000 & NA & 25,889 & 409,889 \\
\hline Romania & 117,095 & 4201 & 1266 & 122,562 \\
\hline Yugoslavia & 115,427 & 1671 & 188,600 & 428,260 \\
\hline Others & 7998 & 1005 & 11,509 & 20,512 \\
\hline TOTAL & 823,208 & 22,621 & 83,099 & $1,676,819$ \\
\hline
\end{tabular}

approximately 1.5 million Anatolian Greeks had already left the country following the Greek retreat in the Turkish War of Independence, and the population exchange agreement provided legitimacy for that de facto emigration (Psomiades 1968, p. 120). The agreement set out some further emigration: during the agreement's implementation, 150,000 Greeks left behind in Anatolia were sent to Greece in return for 360,000 Muslims accepted into Turkey from Greece (Geray 1970, p. 10). The number included both ethnic Turks and the Albanian Muslims from western Greek Macedonia who were classified as Turks at the time of the exchange of populations and were forced to leave their villages for Turkey in 1924 (De Rapper 2000). ${ }^{9}$

There is also an asymmetry that is worth noting regarding the agreementnamely, that while most of the Greek migrations were forced by circumstances, a very large proportion of the Muslims going to Turkey were obliged to do so solely by virtue of the agreement. It not only drastically changed the two countries' demographic characteristics, but also affected their economic activities. To illustrate, with the emigration of the Greek population-historically known as the entrepreneur class of the Ottoman Empire - the newborn Turkey became deficient in trade and industry capacity; at the same time, it gained in agricultural production capacity as the newcomers brought with them important know-how concerning agriculture.

Another state-regulated - not compulsory, merely regulated - agreement was one signed with Bulgaria. The 1925 Treaty of Amity, together with a settlement contract, set rules for protection of Turkish and Bulgarian minorities in Bulgaria and Turkey, respectively, as well as provisions on citizenship and voluntary resettlement (Değerli 2009). According to the Treaty, Turkish and Bulgarian citizens could freely move and settle in each other's countries, provided that they had the religion of the country of settlement. From 1923 until 1939, almost 200,000 people emigrated from Bulgaria to Turkey, a number that dropped considerably in the following period (see Table 5.2).

There were also migrations from Romania. The Romanian government's land confiscation policies, imposed co-habitation with the Vlachs, lack of security for minorities, and heightening economic problems led the ethnic Turks to migrate to Turkey, which had a welcoming immigration strategy at the time. The immigration

\footnotetext{
${ }^{9}$ The exodus of the Muslims from Greece began much earlier; for details, see Baldwin-Edwards and Apostolatou (2008).
} 
of Turks from Romania can be analysed in two stages during the early Republican period: (i) the 1923-1933 migrations, which were lesser in scale and could be characterized as immigrations of small groups of voluntary migrants; and (ii) the 1934-1938 migrations, which were larger flows - of a less voluntary nature - who were received as migrants-to-be-settled by the Turkish state (Duman 2008). This latter interwar period was characterized by the emergence of states where authoritarian regimes were introduced in Central Europe, and when anti-Semitism became an important additional factor, increasing Jewish emigration from Romania (Stola 1992). It was also the time when ethnic purification, rather than assimilation or integration of ethnic minorities, was becoming a dominant idea in Romania (Achim 2001). Accordingly,

Romanian Turks were to benefit from 'a gradual transfer operated by the Turkish government', a reference to a convention signed by the Romanian and Turkish governments on September 4, 1936 that mentioned the possibility of a voluntary emigration of the Moslem Turkish minority living in Dobrudja. The convention had remained in effect, and by April 15, 1941 70,000 ethnic Turks had already left. (Achim 2001, p. 605)

There were also migration flows of Turks from Yugoslavia ${ }^{10}$ during this early Republican period, which were a result of the economic, political, social, and cultural conditions. The world economic crisis of 1929 and the Agricultural Reform Act of 1931 (along with confiscation of the properties of religious and charitable foundations) affected the Turks as the segment of society that owned the largest agricultural lands and whose income had been dependent on agricultural productivity (Öksüz and Köksal 2004). 'The negative effects of the land reform and the confiscation of the properties of the religious and charitable foundations can be seen in a complaint made by the Turks and Albanians to the League of the Nations in 1930' (Öksüz and Köksal 2004, p. 150).

While Turks of Yugoslavia were subjected to political pressures - which made it impossible for them to unite and take action-socially and culturally, they were also devoid of minority rights to vote and for education in their own language. Moreover, there were massacres against the Turks in various parts of Yugoslavia ${ }^{11}$ at the time (Öksüz and Köksal 2004). Thus, based on the official statistics, between 1923 and 1949, some 5894 people within 1449 households emigrated from Yugoslavia to Turkey as permanent immigrants, that is, they were settled by the state, and 111,318 people within 27,030 households came to Turkey as free immigrants, that is, they arrived voluntarily without any state regulation of settlement (Öksüz and Köksal 2004).

It is important to note that in this period, while the importance of religion compared to language was declining in terms of defining the characteristic of these

\footnotetext{
${ }^{10}$ The usage of the name 'Yugoslavia' needs careful exposition of the different territorial names and realities of different periods. Here it refers to the country called Yugoslavia that existed between 1929 and 1946. That country is not the same one as the Federal People's Republic of Yugoslavia in 1946.

${ }^{11}$ Unfortunately, there are no data providing specific information on how many people came from different regions, such as Macedonia.
} 
flows, immigration was still considered more in terms of religion than nationality. The Albanian case was illustrative in this sense, as many Albanians migrated to Turkey between 1918 and 1941, during the colonization of Kosovo by Yugoslavia (De Rapper 2000). Even during this incident, the categories of Albanian, Turk, and Muslim were interchangeable. As described by de Rapper (2000): $:^{12}$

Especially after 1928, measures were taken to encourage the emigration of Albanians to Albania and to Turkey. An agreement was signed in July 1938 between the Yugoslav and Turkish governments, the latter agreeing to take up to 200,000 Albanians, Turks and Muslims from Kosovo and Macedonia (40,000 families). This agreement however was not ratified by the Turkish Parliament and the funds were never released to implement the movement and settlement of refugees in sparsely populated Anatolia. Between 1929 and 1941, however, Yugoslavia strove to organize the departure of Albanians on the basis of international agreements, and managed to provoke a wave of departures to Albania and Turkey.

\subsection{The Cold War Years}

Edirne ${ }^{13}$ resembles the Armageddon

People hugging each other, filled with tears, bewildered

Uprooted and forced to leave

They have a wry look around

Blow thy demented blow, blow

You are not blowing, where are you?

Where on the Earth are you?

Now there you are

A hurricane, a tornado, a thunderstorm

As you are not in Bulgaria

Deliorman is enclosed in gloominess

Birds not singing, leaves not moving

Flowers cut off from the stems

People not smiling

Blow thy demented blow, blow

Tell freely about us, the oppression

To the entire world... (Yalınkılıç 1991, p. 19) ${ }^{14}$

During the period following World War II until the 1990s, there were two kinds of international migration on the Balkan peninsula - ethnic and labour migrations (Bonifazi and Mamolo 2004). Only the former is applicable to the context of Balkan migration to Turkey, which was very political in nature. After the establishment of the Federal People's Republic of Yugoslavia, those parts of the population who were not pleased about the passage to communism, especially among the Turks and

\footnotetext{
${ }^{12}$ Quotation translated by the authors.

${ }^{13}$ The western province of Turkey, which is a point of entry from the Balkans. Also known as 'Ludogorie' in Bulgarian, it is a region that was largely inhabited by Turks.

${ }^{14}$ Quotation translated by the authors.
} 
the Muslims (i.e., Albanians, Bosnians, etc.), began to migrate to Turkey after relations were reinstated by the two countries.

These movements can be categorized as refugee movements, but in a rather different sense than the conventional refugees who are subject to the 1951 Geneva Convention. Kirişci $(1996,1991)$ defines the Turkish refugee system using three categories: The first category is that of convention refugees, who are individuals seeking asylum from European countries and who are subject to the rules and conditions of the Geneva Convention. The second type is non-convention refugees and consists of those coming from non-European countries, such as Iraq, Iran, and Afghanistan. Owing to the geographical limitation that Turkey holds to the Geneva Convention - that is, only asylum seekers from the West can settle in Turkey as refugees - these people are usually resettled in a third country. The third category is that of national refugees, which refers to immigrants of Turkish origin mainly coming from the Balkans, including non-Turkish speaking Muslims, ethnic groups associated with the Turks from Central Asia and the former Soviet Union, and Muslims associated with the Ottoman Empire, such as Albanians, Bosnian Muslims, Pomaks, and Tatars. Thus, the movements mentioned above fit into this third category of so-called national refugees.

Between 1954 and 1990, a total of 185,000 people migrated to Turkey, including-besides those of Turkish origin - many Muslim Albanians and Muslims from Bosnia and Sandjak, who declared themselves to be Turks in order to be able to migrate to Turkey (Kirişci 1995). By 1950, there were 16,079 Albanian speaking, 24,013 Bosnian speaking, and 1605 Serbian speaking Yugoslav migrants in Turkey (Dündar 1999).

The migration flows from Bulgaria to Turkey during the Cold War years can be divided into three stages: (i) 1950-1953, the period shortly after the declaration of a communist state and collectivization of land in Bulgaria when almost 250,000 people of Turkish origin ${ }^{15}$ were granted permission to emigrate from Bulgaria; (ii) following the 1968 family reunification agreements between Turkey and Bulgaria, when more than 95,000 Turks obtained the right to emigrate to Turkey; (iii) in 1989, when the Bulgarian state's assimilation campaign against the Turks incited new migration flows into Turkey. It is important to note that especially for the first two periods, it is rather hard to provide exact figures for the migration flows, as the sources on both sides are biased, either reducing or increasing the numbers based on their own ideological interests (Parla 2003, 2006).

The migration flows of the 1950-1953 period were a result of the policies of the newly-formed communist state, which decided to unify the education system, restrict religious practices, and centralize agricultural production. All of these, besides affecting other Bulgarian citizens, also concerned the Turkish community, which made up almost $10 \%$ of the population in Bulgaria at the time and had enjoyed considerable freedom both in practising their religion, language, and traditions, and in running their own schools (Beltan 2006, p. 25). As a result of these policies,

\footnotetext{
${ }^{15}$ The number included Pomaks who were considered to be of Turkish origin through their Islamic orientation, but there are no data differentiating this group from the larger Turkish minority.
} 
154,393 Bulgarian Turks migrated to Turkey between January 1950 and November 1951. They were accepted by the Turkish as settled immigrants and received financial support (Beltan 2006, p. 25).

Estimates of the number of Turks migrating from Bulgaria to Turkey after the 1968 agreements (which aimed at uniting separated families), vary from 50,000 to 130,000 depending on the source (Parla 2003, 2006). Parla (2003, p. 562) argues that these migrations 'depended not only on the political regimes in Bulgaria, but also on those in Turkey, with the latter's attitudes towards its "racial kin" (soydas) ranging from welcoming to indifference to reluctant acceptance, contingent on the political and economic climate'.

The third stage of migration flows from Bulgaria to Turkey was during the socalled Revival Process in Bulgaria, which was an assimilation campaign that began in 1984 with bans on wearing traditional Turkish dress and speaking Turkish in public places. It continued with a name-changing campaign targeting Turks. As a result of this assimilation campaign, almost 350,000 Bulgarian Turks ${ }^{16}$ migrated to Turkey between June 1989 and August 1989 (Kirişci 1995, pp. 63-66).

The Revival Process was implemented not only in Bulgaria, but was part of a socialistic unification policy in all of the communist regimes of the Balkans. Thus, during the Cold War period, immigrants from other Balkan countries also disembarked to Turkey. After Bulgaria, the second largest population movement from the Balkans was from Yugoslavia, from where 186,925 people migrated to Turkey between 1945 and 1990 (Kirişci 1995, p. 70). As Yugoslavia did not permit migration of the Turkish and Muslim community during the period 1939-1950, it was only after the political rapprochement between Yugoslavia and Turkey and the signing of the Balkan Pact in the later period that most of these people could take their leave (Altuğ 1991, p. 115; Eren 1993, p. 296; Beltan 2006, pp. 25-28). From the 1950s to the 1960s, approximately 150,000 immigrants arrived in Turkey composed not only of Turks, but also Albanians, Pomaks, and Bosnians (Beltan 2006, pp. 25-28). Concerned about their status in post-war communist Yugoslavia, even those Muslim Albanians who could not speak Turkish claimed Turkish ancestry in order to use this immigration status (Kirişci 1995, p. 71; Poulton 1991, p. 92).

In this sense, Albanians were an interesting case. Until 1948, the Albanians of Yugoslavia benefited from the situation created by the good relations between Albania and Yugoslavia. However, as Yugoslavia broke its ties with the USSR and its satellites, including Albania, the Albanians of Yugoslavia started to be suspected of being manipulated by Albania and aiming to destabilize Yugoslavia (De Rapper 2000).

Although an Albanian state had emerged from the Ottoman Empire, many Muslim Albanians took advantage of various emigration agreements between Yugoslavia and Turkey, and seeing Turkey rather than Albania as their kin-state, moved to there; this could be explained largely by Enver Hoxha's post-war fortress mentality and militant atheism (Poulton 1997, p. 200).

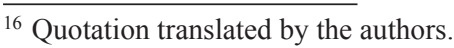


With the 1953 Balkan Pact, many Albanians began to depart for Turkey. There were three novel characteristics of this new wave of departures (Poulton 1997, p. 200). First, in addition to the political dimension of the previous departures, there was a national dimension of these movements. While political opposition was still a characteristic of Albanians - anti-communist sentiments among them were widespread - there was also resentment among those people who had passed 'religion before the nation'. Secondly, in order to legally migrate to Turkey in line with the Balkan Pact, Albanians pretended to be members of the Turkish minority. According to De Rapper (2000), one third of the people who then declared themselves as Turks did not speak Turkish. Thirdly, though 20 years after the previous wave, these latter immigrants benefited from the existence of an Albanian community in Turkey with family ties, which facilitated their rapid integration.

Following the consolidation of the communist regime in Yugoslavia and an improving minority status, from the 1970 s to 1980 s migration to Turkey declined noticeably. Only 1797 people — most of whom were joining close relatives - chose to migrate to Turkey in this period (Table 5.3; Beltan 2006, pp. 25-28; Kirişci 1995, p. 71).

During the years of the Cold War, migration from Greece was the third largest demographic movement to Turkey after those from Bulgaria and Yugoslavia. In the course of World War II and the subsequent civil war in Greece, many Muslims from Greece were granted asylum in Turkey (Kirişci 1995). It was only after the internal situation had returned to normal in 1951 that Turkey ended its policy of admitting Muslims from Greece. Subsequently, approximately 26,000 Muslims from Greece migrated to Turkey during the 1950s and 1960s (Beltan 2006, pp. 25-28; Kirişci 1995, pp. 72-73). ${ }^{17}$

The smallest migration flows during the Cold War years came from Romania, with only 1200 immigrants arriving in Turkey. This small number can be explained by the fairly liberal cultural and minority rights that the Turkish community enjoyed in Romania ${ }^{18}$ after World War II (Kirişci 1995, p. 74). Accordingly, it would not be wrong to argue that while bilateral relations were also important, the levels of migration from the Balkans during this period were highly correlated with the internal

Table 5.3 The Turkish population in the FR Yugoslavia according to official documents. (Source: Geray 1962, pp. 10-14)

\begin{tabular}{l|l|l|l|l|l}
\hline Area & 1948 & 1953 & 1961 & 1971 & 1981 \\
\hline Kosovo & 1315 & 34,583 & 25,764 & 12,244 & 12,513 \\
\hline Macedonia & 95,940 & 203,908 & 131,481 & 108,552 & 86,691 \\
\hline Yugoslavia & 97,255 & 229,672 & 157,245 & 120,796 & 101,291 \\
\hline
\end{tabular}

\footnotetext{
${ }^{17}$ There are no data available for the war period between 1939 and 1945.

18 To illustrate, Turks have comprised almost $2 \%$ of the population in Northern Dobrudja from the 1950 s until today.
} 
politics of the Balkan countries - especially with their treatment of their minorities. The reasons for migration to Turkey in the next period were rather different.

\subsection{Current Stage}

The end of the Cold War had two main consequences for migration dynamics in the Balkans. First, the transition stage from communist totalitarian regimes to capitalist democracies generated ethnic conflicts in the former Yugoslavia, which produced certainly the most dramatic forced ethnic migrations on the European continent in the last two decades (Bonifazi and Mamolo 2004). Secondly, this transition formed the political and economic foundations for the extension or emergence of a series of migration flows that previously had been strictly controlled by states. Generally, it can be argued that while migrations of the previous periods were more ethnoreligious in character, the current movements from the Balkans to Turkey can be characterized more as labour migrations ${ }^{19}$ - maybe with the two exceptions of the Bosnian Muslims and Kosovars who took refuge in Turkey during the dissolution of the former Yugoslavia. Although there are no statistics, in the case of Muslims from Greece (i.e., Turks and Pomaks) an important reason for migration to Turkey is also for continued education at university level.

Turkey accepted Bosnian Muslims as refugees after the outbreak of hostilities and persecutions in Bosnia-Herzegovina in 1992 where a total of 2819 Bosnian refugees were housed in refugee camps located in different cities of Turkey (Kirişci 1995, pp. 71-72). Between 1992 and 1995, around 20,000 Bosnians were granted temporary asylum; many have returned to Bosnia since the adoption of the Dayton Peace Agreement (İçduygu and Sert 2009). Similarly, in 1998 and 1999, about 18,000 Kosovars took shelter in Turkey and benefited from protection from the ethnic strife in their homeland, of whom a majority returned with the lessening of the conflict in Kosovo (Kirişci 2001).

With the fall of communism, Turkey became a strategic choice of emigration destination for Muslim Albanians from Albania, due to the presence of networks, existing relations, the lack of entry requirements (most migrants buy a tourist visa at the border), and the absence of anti-foreigner and anti-Albanian racism. There were two main waves (De Rapper 2000). The first was during the so-called 'crisis of embassies' in July 1990 in Tirana, when hundreds of people took refuge in foreign embassies. The Embassy of Turkey hosted about 30 people who settled in Turkey with the help of the authorities, promoting the arrival of others later on the basis of kinship networks. These first arrivals were mostly fathers. Once the situation was stabilized they brought their families. For a number of them, Turkey became a transit point for other countries, especially the USA.

\footnotetext{
${ }^{19}$ While ethno-religious elements are still important, non-Muslims from the Balkans are also involved in these current movements.
} 
The second wave was in 1997 and 1998, during the economic and political crises and rising corruption in Albania, when some 6500 families - 42,000 people - arrived in Turkey (De Rapper 2000). Rather than the migration of fathers of families or young single men seeking employment abroad, this wave was for the purpose of taking the family to safety and ensuring normal living conditions.

Much of the recent migration flows from the Balkans to Turkey are a result of economic difficulties in the home countries. These movements are usually of irregular labour migrants, most of whom are from Bulgaria and Romania and arrive in Turkey on tourist visas to work informally as domestic labourers, sex workers, construction workers, or sweatshop workers (İçduygu and Yükseker 2008). Many of these migrants come to Turkey legally, in line with Turkish visa requirements, but overstay their visas and then become illegal while in the country (İçduygu 2009). Thus, while many economic sectors in western Turkey-mainly the textile, construction, sex, and entertainment industries - hinge on this type of cheap labour, upper and middle-class Turkish families provide work for female domestic helpers as nannies, babysitters, or carers for the sick and elderly (İçduygu and Yükseker 2008). These people's working conditions are precarious, with long hours and low wages - without social security, health insurance, or pension schemes.

The case of Romanian migration to Turkey is illustrative in showing that these countries are now part of a migration system in which economic conditions, not only in these countries themselves, but in the entire region, affect patterns of movement. For example, the first wave of Romanian migration took place from 1990 to 1995. During this period a new pattern of mass migration of Romanian-speaking Christian Romanians to the Turkish labour market emerged which was quintessentially transnational - that is, "they worked in the host countries for fixed periods of time, stipulated in their work contracts, and were not joined by their families' (Ban 2009 , p. 5). At that time, Turkey was a major destination for traders and informal service workers; once migration networks for the Italian, Spanish, and Greek labour markets started to consolidate in the second half of the 1990s, and economic opportunities shortly became modest for the prospective migrant in Turkey, the number of Romanian migrants in Turkey decreased substantially (Ban 2009, p. 5).

At the same time, it is possible to speak of a return migration to the Balkans from Turkey. With the regime change in Bulgaria in 1990, one third of the refugees who had arrived in the previous period returned, while the rest remained and acquired Turkish citizenship. Based on the figures provided for 2006 by the Bureau for Foreigners, Borders, and Asylum of the Directorate of General Security of the Ministry of Interior, Bulgarians still constitute the largest nationality with residence permits in Turkey (İçduygu and Sert 2009). However, following Bulgaria's recent accession to the EU, an increasing number of these Turks of Bulgarian origin have again applied for Bulgarian citizenship so as to obtain the right to travel to Bulgaria and to other EU countries without a visa.

Data confirm the decreasing scale of immigration from the Balkans to Turkey. Based on 31 December 2012 population and housing census data provided by the Turkish Statistical Institute (TUIK), around 1.3\% of Turkey's population were born 
abroad. While around $43 \%$ of this group were born in Bulgaria, approximately $8.7 \%$ and $3.5 \%$ were born in Macedonia and Greece, respectively. Bulgaria remains a part of migration trends towards Turkey, albeit of lesser importance. Compared to the 1980s, when Bulgarian migrants were the second largest group of immigrants in Turkey, they currently form around only $2 \%$ of the migrant stock.

Figures provided by the Ministry of Interior also show a declining trend of immigration from Bulgaria and the Balkans in general. Until 2008, around 30\% of immigration in Turkey was from this region; subsequently, the proportion decreased to $12 \%$. One explanation for this decline is the accession of Bulgaria and Romania, two important migrant-sending countries, to the EU-leaving Turkey as a less attractive destination compared with the new opportunities in the EU (Sert and Korfali). Although there was a small upwards trend in 2010 , to $16 \%$ right after the eurozone crisis, it fell back to $10 \%$ in 2012. Looking at these numbers, one might claim that immigration from the Balkans to Turkey has taken a more rational volume and that migrants seem to be making their decisions based on economic interests rather than ethnic kinship ties.

\subsection{Conclusion}

Looking at the migration patterns from the Balkans into Turkey through a longitudinal analysis, we can apply Parla's claim for the Bulgarian case to the entire Balkans and argue that Turkey's attitudes towards these migrations ranged from reluctant acceptance or welcoming its 'racial kin' to indifference towards irregular migrants, depending on the political and economic environment. The late Ottoman period can be characterized as 'reluctant acceptance' of immigrants, as settlement and management of these people constituted an important problem for the Empire in its decline. Then, the early years of the Republic are a typical example of the 'welcoming' attitude towards the 'racial kin' from the Balkans. This was in line with the founding fathers' desire to increase the population of the war-torn and epidemicrife Anatolia. The years of the Cold War were a direct reflection of the political and economic climate. In this period we observe many fluctuations in migration flows, which are largely ethnic in character, depending on the home countries' treatment of minorities. The current stage of Balkan migrations to Turkey is rather differentwith less importance of ethnic kin, more significance of economic conditions, more two-way flows, and indifference on the part of the authorities towards the situation of irregular labour migrants. All in all, Balkan migrant flows to Turkey represent a lively migration system that has adapted to changing local, bilateral, and global conditions over time.

Open Access This chapter is distributed under the terms of the Creative Commons Attribution Noncommercial License, which permits any noncommercial use, distribution, and reproduction in any medium, provided the original author(s) and source are credited. 


\section{References}

Achim, V. (2001). The Romanian population exchange project. Elaborated by S. Manuila in October 1941. www.iini-minorities.ro/docs/V.Achim-Project 2001.pdf. Accessed 1 Jan 2011.

Ağanoğlu, H. Y. (2001). Osmanlıdan Cumhuriyete Balkanların makus talihi: Göç [Ill-fated Balkans from Ottomans to Republic: Migration]. Istanbul: Kum Saati Yayınları.

Ahmad, F. (1993). The making of modern Turkey. London: Routledge.

Altuğ, Y. (1991). Balkanlardan anayurda yapılan göçler [Migrations from Balkans to the motherland]. Ankara: Türk Tarih Kurumu.

Anderson, F. M., \& Hershey, A. M. (1918). Handbook for the diplomatic history of Europe, Asia, and Africa, 1870-1914. Prepared for the National Board for Historical Service. Washington, DC: Government Printing Office.

Atay, F. R. (1970). Taymis kıyıları [Taymis shores]. Istanbul: Baha Matbaas1.

Aydemir, Ş. S. (1932). Çok nüfuslu Anadolu [Anatolia with numerous population]. Kadro, 2(5), 35 .

Babuş, F. (2006). Osmanlı'dan günümüze etnik-sosyal politikalar çerçevesinde göç ve iskan siyaseti ve uygulamalarl [Ethnic-social policies from Ottomans to present: Migration and settlement policies and applications]. Istanbul: Ozan Yayınları.

Baldwin-Edwards, M., \& Apostolatou, K. (2008). Foreword: Ethnicity and migration, a Greek story. Migrance, 31, 5-17.

Ban, C. (2009). Economic transnationalism and its ambiguities: The case of Romanian migration to Italy. International Migration. doi:10.1111/j.1468-2435.2009.00556.x.

Beltan, S. B. (2006). Citizenship and identity in Turkey: The case of the post-1980 Turkish-Muslim immigrants from Macedonia. Masters thesis, Boğaziçi University, Istanbul.

Bonifazi, C., \& Mamolo, M. (2004). Past and current trends of Balkan migrations. Espace populations sociétés [online], 2004/3 | 2004. http://eps.revues.org/index356.html. Accessed 22 Jan 2009.

Çağaptay, S. (2002). Kemalist dönemde göç ve iskan politikaları: Türk kimliği üzerine bir çalışma [Migration and settlement policies of Kemalist period: A study on Turkish identity]. Toplum ve Bilim, 93 (pp. 218-241).

Courbage, Y., \& Fargues, P. (1998). Christians and Jews under Islam. London: I. B. Tauris.

De Rapper, G. (2000). Les Albanais à Istanbul [Albanians in Istanbul]. Dossiers de 1'IFEA 3. Istanbul: Institut Français d'Etudes Anatoliennes, Georges Dumézil (IFEA). www.ifea-istanbul. net/dossiers ifea/Bulten 03.pdf.

Değerli, E. S. (2009). Balkan Pact and Turkey. Uluslararası Sosyal Araştırmalar Dergisi, 2(6), $137-147$.

Deringil, S. (2000). The Ottomans, the Turks, and world power politics. Istanbul: Isis Press.

Duman, Ö. (2008). Atatürk döneminde Romanya'dan Türk göçleri (1923-1938) [Turkish migrations from Romania during Atatürk period]. Bilig, 45, 23-44.

Dündar, F. (1999). Türkiye nüfus sayımlarında azınlıklar [Minorities in Turkish censuses]. Istanbul: Doz Yayıncilık.

Dündar, F. (2001). Ittihat ve Terakki'nin Müslümanları iskan politikası [The Muslim settlement policy of Unity and Progress]. Istanbul: İletişim.

Eren, H. (1993). Balkanlarda Türk ve diğer Müslüman toplumları ve göç olgusu [Turkish and other Muslim communities in the Balkans and migration phenomenon]. Istanbul: Eren Yayınc1lik.

Geray, C. (1962). Türkiye'den ve Türkiye’ye Göçler, Türk İktisadi Gelişmesi Araştırma Projesi (Teksir). Ankara: SBF Maliye Enstitüsü.

Geray, C. (1970). Türkiye'de göçmen hareketleri ve göçmenlerin yerleştirilmesi [Migratory movements and the settlement of migrants in Turkey]. Amme Idaresi Dergisi, 3(4), 8-36.

İçduygu, A. (2009). SOPEMI report for Turkey. The Continuous Reporting System on Migration (SOPEMI) of the Organisation for Economic Co-operation and Development (OECD), Istanbul.

İçduygu, A., \& Kirişci, K. (2009). Land of diverse migrations. Istanbul: Bilgi University Press. 
İçduygu, A., \& Sert, D. (2009). Country profile: Turkey, Focus Migration 5. Hamburg: Hamburg Institute of International Economics (www.focus-migration.de).

İçduygu, A., \& Yükseker, D. (2008). Rethinking the transit migration in Turkey: Reality and representation in the creation of a migratory phenomenon. Paper prepared for IMISCOE Conference '(Irregular) Transit Migration in the European Space: Theory, Politics, and Research Methodology', Istanbul, 18-19 April.

İçduygu, A., Çolak, Y., \& Soyarık, N. (1999). What is the matter with citizenship? A Turkish debate. Middle Eastern Studies, 35(4), 187-208.

İçduygu, A., Toktas, S., \& Soner, B. A. (2007). The politics of population in a nation-building process: Emigration of non-Muslims from Turkey. Ethnic and Racial Studies, 31(2), 358-389.

İpek, N. (1999). Rumeli'den Anadolu'ya Türk göçleri [Turkish migration from Rumeli to Anatolia]. Ankara: Türk Tarih Kurumu Yayınları.

Kadıoğlu, A. (1998). Milletini arayan devlet: Turk milliyetçiliğinin açmazları [State seeking its nation: The dilemmas of Turkish nationalism]. In A. Ünsal (Ed.), 75 Yllda tebaa'dan yurttaşa doğru [From subject to citizen in 75 years]. Istanbul: Türkiye Ekonomik ve Toplumsal Tarih Vakfi, İş Bankası Yayınları.

Keyder, Ç. (1989). Türkiye'de devlet ve sinuflar [State and social classes in Turkey]. Istanbul: İletişim Yayınları.

Keyman, E. F., \& İçduygu, A. (1998). Türk modernleşmesi ve ulusal kimlik sorunu: anayasal vatandaşlık ve demokratik açılım olasılığ 1 [The Turkish modernization and national identity question: Constitutional citizenship and a new democratic approach]. In A. Ünsal (Ed.), 75 Yılda tebaa'dan yurttaşa doğru [From subject to citizen in 75 years] (pp. 169-180). Istanbul: Türkiye Ekonomik ve Toplumsal Tarih Vakfı, İș Bankası Yayınları.

Kirişci, K. (1991). The legal status of asylum seekers in Turkey: Problems and prospects. International Journal of Refugee Law, 3(3), 510-528.

Kirişci, K. (1995). Post Second World War immigration from Balkan countries to Turkey. New Perspectives on Turkey, 12(Spring), 61-78.

Kirişci, K. (1996). Refugees of Turkish origin: "Coerced immigrants" to Turkey since 1945. International Migration, 34, 385-412.

Kirişci, K. (2000). Disaggregating Turkish citizenship and immigration practices. Middle Eastern Studies, 36(3), 1-22.

Kirişci, K. (2001). UNHCR and Turkey: Cooperating towards an improved implementation of the 1951 convention on the status of refugees. International Journal of Refugee Law, 13(1/2), 71-97.

Kocacık, F., \& Yalçın, C. (2008). Forced migration from the Balkans to Anatolia: 1878-1900. Sosyal Bilimler Dergisi, 20, 251-262.

McCarthy, J. (1995). Death and exile: The ethnic cleansing of Ottoman Muslims, 1821-1922. Princeton: Darwin Press.

Meeker, M. E. (2002). A nation of empire: The Ottoman legacy of Turkish modernity. Berkeley: University of California Press.

Öksüz, H. (2004). The reasons for immigration from Western Thrace to Turkey: 1923-1950. Turkish review of Balkan studies (Vol. 9, pp. 249-278). Istanbul: Foundation for Middle East and Balkan Studies.

Öksüz, H., \& Köksal, Ü. (2004). Emigration from Yugoslavia to Turkey (1923-1960). Turkish review of Balkan studies (Vol. 9, pp. 145-177). Istanbul: Foundation for Middle East and Balkan Studies.

Özbudun, E. (1998). Milli mücadele ve Cumhuriyet'in resmi belgelerinde yurttaşlık ve kimlik sorunu [The citizenship and identity question in the official documents of the national liberation and the Republic]. In A. Ünsal (Ed.), 75 Yılda tebaa'dan yurttaşa doğru [From subject to citizen in 75 years] (pp. 151-168). Istanbul: Türkiye Ekonomik ve Toplumsal Tarih Vakfı, İş Bankası Yayınları.

Özdoğan, G. (1996). Türk ulusçuluğunda 1rkçı temalar: 1930 ve 40'ların Türkçü akımı [Racist elements in Turkish nationalism: Turkish currents of the 1930s and 1940s]. Toplumsal Tarih, $29,19-24$. 
Parla, A. (2003). Marking time along the Bulgarian-Turkish border. Ethnography, 4, 561-575.

Parla, A. (2006). Longing, belonging and locations of homeland among Turkish immigrants from Bulgaria. Southeast European and Black Sea Studies, 6(4), 543-557.

Poulton, H. (1991). Balkans: Minorities and states in conflict. London: Minority Rights Group.

Poulton, H. (1997). Turkey as a kin-state: Turkish foreign policy towards Turkish and Muslim communities in the Balkans. In H. Poulton \& S. Taji-Farouki (Eds.), Muslim identity and the Balkan state (pp. 194-213). London: Hurst and Company.

Psomiades, H. J. (1968). The eastern question: The last phase. Thessaloniki: Institute for Balkan Studies.

Sert, D., \& Korfali, D. K. (no date). On fringes of 2004 enlargement: Changing patterns of CEE migration within Turkey, unpublished manuscript.

Stola, D. (1992). Forced migrations in Central European history. International Migration Review, 26(2), 324-341 (Special issue on the New Europe and international migration).

Tekeli, İ. (1990). Osmanlı İmparatorluğu'ndan günümüze nüfusun zorunlu yer değiştirmesi ve iskan sorunu [The issue of forced misplacement and settlement from Ottoman Empire to date]. Toplum ve Bilim, 50 (pp. 49-71).

Todorova, M. (1997). Balkanları tahayyül etmek [Imagining the Balkans]. Istanbul: İletişim Yayınları.

Ulker, E. (2007). Assimilation of the Muslim communities in the first decade of the Turkish Republic (1923-1934). European Journal of Turkish Studies. www.ejts.org/document822.html.

Ulukan, N. C. (2008). Göçmenler ve işgücü piyasası: Bursa'da Bulgaristan göçmenleri örneği [Migrants and employment market: The example of Bulgarian migrants in Bursa]. PhD dissertation, Marmara University, Istanbul.

Yalınkılıç, Y. (1991). Es bre deli rüzgar es [Blow thy demented blow, blow]. Bulgaristan Türklerinin Sesi, 5, 19.

\begin{abstract}
Ahmet İçduygu is professor of international relations and director of the Migration Research Program (MiReKoç) at Koç University, Istanbul, Turkey. His areas of interest are international migration, Turkey, demography, irregular migration, citizenship, international organizations, and civil society. Içduygu is co-editor of Migration around Turkey: Old phenomena, new research, Istanbul: Isis Press, 2013 (with Deniz Yükseker and Damla B. Aksel) and of Countries of migrants, cities of migrants, Istanbul: Isis Press, 2013 (with Marcello Balbo and Julio Pérez Serrano)
\end{abstract}

Deniz Sert is Assistant Professor at the Department of International Relations, Özyeğin University, Istanbul, Turkey. Her areas of interests are conflict, international migration, forced migration, internal displacement, transnationalism, border management, and civil society. Two of her recent publications are 'Turkey's integrated border management strategy?', Turkish Policy Quarterly, 12(2013), nr. 1, pp. 173-179 and 'Compensation Packages,' in L. Stan and N. Nedelsky (eds.) The new encyclopedia of transitional justice, New York: Cambridge University Press, 2013 